Ksenia Szymanek-Majchrzak ${ }^{1^{*}}$, Jakub Kosiński ${ }^{1}$, Katarzyna Żak, Katarzyna Sułek ${ }^{1}$ Andrzej Młynarczyk², Grażyna Młynarczyk ${ }^{l}$

\title{
PREVALENCE OF METHICILLIN-RESISTANT AND MUPIROCIN-RESISTANT STAPHYLOCOCCUS AUREUS STRAINS AMONG MEDICAL STUDENTS OF MEDICAL UNIVERSITY OF WARSAW
}

\author{
OCENA WYSTĘPOWANIA METICYLINO-OPORNYCH ORAZ MUPIROCYNO- \\ OPORNYCH SZCZEPÓW STAPHYLOCOCCUS AUREUS WŚRÓD STUDENTÓW \\ MEDYCYNY WARSZAWSKIEGO UNIWERSYTETU MEDYCZNEGO
}

\author{
${ }^{1}$ Department of Medical Microbiology, Medical University of Warsaw; \\ T. Chalubinskiego 5 Str., 02-004 Warsaw, Poland \\ ${ }^{2}$ Department of Medical Microbiology, The Infant Jesus Teaching Hospital; \\ Lindleya 4 Str., 02-005 Warsaw, Poland \\ ${ }^{1}$ Katedra i Zakład Mikrobiologii Lekarskiej, Warszawski Uniwersytet Medyczny, \\ ul. T. Chałubińskiego 5, 02-004 Warszawa \\ ${ }^{2}$ Zakład Mikrobiologii Lekarskiej, Szpital Kliniczny Dzieciątka Jezus, ul. WH Lindleya 4, 02-005 Warszawa
}

\begin{abstract}
INTRODUCTION. Staphylococcus aureus is a microorganism, which is able to colonize the human body without any pathogenic effect, but it also can cause life-threatening infections (opportunistic pathogen). Asymptomatic colonization with both methicillin resistant (MRSA) and methicillin susceptible (MSSA) S.aureus strains state is an important predisposing factor for infections. The risk of infection for carriers of MSSA is even three-times higher than for non-colonized people, and in the case of MRSA it is even four-times higher than in MSSA carriers. Carriers can be also a source of infection for other people, especially those belonging to high-risk groups. The drug of choice used for the local eradication of S.aureus is mupirocin (Mup). In recent years, the failure of decolonization therapy has been observed. The aim of the study was to assess and compare the level of colonization of S.aureus (MRSA or MSSA) among medical students and to evaluate the sensitivity of the strains to mupirocin. For MRSA/MupRSA isolates the molecular mechanism of resistance phenotype was determined. MATERIALS AND METHODS. 955 swabs from 2014-2016 from pre-clinical students of medicine of the Medical University of Warsaw. The strains were identified using Pastorex-Staph-Plus (BioRad) and/or the VITEK-MS system (Biomerieux), according to manufacturer's instructions. Susceptibility to methicillin and mupirocin was determined by disk diffusion and/or broth microdilution method, according to EUCAST. The presence of the mecA/mec $\mathrm{C}$ and mupA genes were detected with PCR technique.

RESULTS. Asymptomatic colonization with S.aureus strains was found in 245/955 (25,7\%) students, in particular years in the range of 21,7-29,9\%. 243 isolates expressed the MSSA/MupSSA phenotype, one strain was resistant to mupirocin MSSA/MupRSA (genotype mecA/mecC-negative, mupA-positive) and one showed simultaneous resistance to methicillin and mupirocin (mecA/mupA-positive genotype). The level of MRSA and MupRSA colonization was $0,1 \%$ and $0,2 \%$, respectively.

SUMMARY AND CONCLUSIONS. The level of S.aureus colonization among surveyed students, didn't differ from the norm for a generally healthy population, but showed an upward trend. The carriage of S.aureus, especially of multi-resistant strains among medical students at the beginning of their clinical activities, consist of a real threat to patients and other people.
\end{abstract}

Keywords: asymptomatic colonization, MRSA, mupirocin, nasal carriage, Staphylococcus aureus

STRESZCZENIE

WPROWADZENIE. Staphylococcus aureus jest drobnoustrojem, który może bezobjawowo kolonizować człowieka, ale może również wywoływać zagrażające życiu zakażenia (patogen oportunistyczny). Bezobjawowa

(c) National Institute of Public Health - National Institute of Hygiene / Narodowy Instytut Zdrowia Publicznego - Państwowy Zakład Higieny 
kolonizacja zarówno wariantami meticylino-opornymi (MRSA), jak i wrażliwymi (MSSA) stanowi istotny czynnik predysponujący do zakażeń. Ryzyko infekcji u nosicieli MSSA jest nawet trzykrotnie wyższe w porównaniu do osób nieskolonizowanych, a w przypadku MRSA nawet czterokrotnie wyższe w porównaniu do nosicieli MSSA. Nosiciele mogą stanowić źródło zakażenia dla innych osób, zwłaszcza należących do grup podwyższonego ryzyka. Lekiem z wyboru stosowanym do miejscowej eradykacji S.aureus jest mupirocyna (Mup). W ostatnich latach coraz częściej obserwuje się niepowodzenia terapii dekolonizacyjnej. Celem badań była ocena oraz porównanie poziomu kolonizacji S.aureus (MSSA lub MRSA) wśród studentów medycyny oraz ocena wrażliwości wyizolowanych szczepów na mupirocynę. Dla MRSA/MupRSA określono mechanizm molekularny determinujący fenotyp oporności.

MATERIALY I METODY. 955 wymazów z lat 2014-2016 od studentów przedklinicznych kierunku lekarskiego WUM. Szczepy identyfikowano przy użyciu Pastorex-Staph-Plus (BioRad) i/lub systemu VITEK-MS (Biomerieux), zgodnie z instrukcją producenta. Wrażliwość na meticylinę oraz mupirocynę określano metodą dyfuzyjno-krążkową i/lub mikro-rozcieńczeń w podłożu płynnym, wg EUCAST. Geny mecA/mecC oraz mupA wykrywano przy użyciu techniki PCR.

WYNIKI. Bezobjawową kolonizację szczepami S.aureus stwierdzono u 245/955 (25,7\%) osób, w poszczególnych latach w zakresie 21,7-29,9\%. 243 izolaty wykazywały fenotyp MSSA/MupSSA, jeden szczep wykazywał oporność na mupirocynę MSSA/MupRSA (genotyp mecA/mecC-negatywny, mupA-pozytywny) i jeden wykazywał jednoczesną oporność na meticylinę oraz mupirocynę (genotyp mecA/mupA-pozytywny). Poziom kolonizacji MRSA oraz MupRSA wynosił odpowiednio 0,1\% oraz $0,2 \%$.

PODSUMOWANIE I WNIOSKI. Poziom kolonizacji S.aureus wśród badanych studentów nie odbiegał od normy dla populacji ogólnie zdrowej, ale wykazywał tendencję wzrostową. Nosicielstwo S.aureus, a zwłaszcza wieloleko-opornych szczepów wśród studentów medycyny rozpoczynających zajęcia kliniczne, jest realnym zagrożeniem dla pacjentów oraz innych osób z kontaktu.

Slowa kluczowe: bezobjawowa kolonizacja, MRSA, mupirocyna, nosicielstwo w jamie nosowej, Staphylococcus aureus

\section{INTRODUCTION}

Methicillin-resistant Staphylococcus aureus (MRSA) strains are classified as one of the most dangerous human pathogens. According to the Regulation of the Minister of Health, they are the first on the current list of "alarm pathogens" (1). The importance of this international problem is emphasized by the fact that world-class experts at the World Health Organization, during a meeting in Geneva in February 2017, decided to place MRSA strains on the global priority pathogens list (global PPL) of antibioticresistant bacteria, which includes twelve most dangerous pathogens posing a threat to public health $(2,3)$.

S. aureus is an opportunistic pathogen that can cause a wide spectrum of disease symptoms, both in hospital and non-hospital settings (4). MRSA strains, in which the mechanism of resistance is associated with the presence of the mecA genes (healthcare associated MRSA - HA-MRSA, community aquired MRSA - CA-MRSA) or mecC (some livestock associated MRSA - LA-MRSA), transmitted on staphylococcal cassette chromosome mec (SCCmec), coding for a modified PBP2a protein, show a lack of susceptibility to almost all beta-lactam antibiotics (except for ceftaroline and ceftobiprol), making them even more dangerous (especially CA-MRSA) compared to classic methicillin-susceptible $S$. aureus isolates (MSSA) $(5,6)$. In 2018, the mecB gene was described in $S$. aureus in the large pSAWWU4229_1

\section{WSTĘP}

Meticylino-oporne szczepy Staphylococcus aureus (methicillin-resistant S. aureus, MRSA) są zaliczane do jednych $\mathrm{z}$ najbardziej niebezpiecznych ludzkich patogenów. Zgodnie z Rozporządzeniem Ministra Zdrowia, znajdują się na pierwszym miejscu obowiązującej listy „patogenów alarmowych” (1). Rangę problemu na skalę międzynarodową podkreśla fakt, iż światowej klasy eksperci World Health Organization, podczas spotkania w Genewie w lutym 2017 roku zdecydowali o umieszczeniu szczepów MRSA na liście dwunastu najbardziej niebezpiecznych patogenów "global priority pathogens list (global PPL) of antibiotic-resistant bacteria", stanowiących zagrożenie dla zdrowia publicznego $(2,3)$.

$S$. aureus jest patogenem oportunistycznym, który może wywoływać szerokie spektrum objawów chorobowych, zarówno w warunkach szpitalnych, jak i pozaszpitalnych (4). Szczepy MRSA, u których mechanizm oporności związany jest $\mathrm{z}$ obecnością genów mecA (health-care associated MRSA, HA-MRSA; community acquired MRSA, CA-MRSA) lub mecC (niektóre livestock associated MRSA, LA-MRSA), przenoszonych na gronkowcowych kasetach chromosomowych SCCmec (staphylococcal cassette chromosome mec), kodujących zmodyfikowane białko PBP2a, wykazują brak wrażliwości na prawie wszystkie antybiotyki beta-laktamowe (z wyjątkiem ceftaroliny i ceftobiprolu), co czyni je jeszcze bardziej niebezpiecznymi (zwłaszcza CA-MRSA), w porównaniu do klasycznych izolatów MSSA (methicillin-susceptible S. aureus) (5, 6). W 2018 roku 
plasmid of 84,599 bp together with resistance genes to aminoglycosides, macrolides and tetracyclines. The $m e c \mathrm{~B}$ gene conditioned a similar resistance phenotype to beta-lactam antibiotics as the mecA and $m e c \mathrm{C}$ genes (7). The mec $\mathrm{D}$ gene was also described in Macrococcus caseolyticus in 2018, which was expressed in a $S$. aureus strain, and the spectrum of conditioned resistance comprised all beta-lactam antibiotics, including ceftaroline (8). Methicillin resistance in HA-MRSA phenotype variants is most often accompanied by resistance to antibiotics from other groups, which makes them even more dangerous, especially for patients with immunity disorders (5). $S$. aureus is an important component of human flora, and usually $10-30 \%$ of people in the general population are carriers, which can be an important predisposing factor for endogenous infections. The risk of infection in asymptomatically colonized people is at least three times higher than in non-carriers, and the risk of symptomatic infection in the case of MRSA strains is even four times higher compared to MSSA (9). Asymptomatic colonization is also an important risk factor for the microorganism transmission from the host to other people or the environment, which is a potential threat especially for hospitalized patients. Moreover, there is also a risk of horizontal transfers of mec genes to other $S$. aureus strains and/or other species within the genus Staphylococcus in case of mecB-positive MRSA isolates, if this type of resistance will spread in $S$. aureus $(5,7)$.

People who, due to their profession, have direct contact with patients: doctors, nurses, midwives, paramedics, but also medical students, should not pose a threat of infection with these dangerous pathogens.

Mupirocin is commonly used for local $S$. aureus eradication in the nasal cavity (efficacy of 4-7 day therapy is at the level of 90\%). Mupirocin acts on bacterial cells by blocking isoleucine-tRNA synthetase, IleS, leading to protein biosynthesis inhibition (10). Mupirocin induces a bactericidal effect against Grampositive microorganisms, including $S$. aureus both MSSA and MRSA. However, in recent years, cases of failure of $S$. aureus decolonization using mupirocin have been increasingly frequently reported, which is associated with the emergence of non-susceptible variants to this drug (mupirocin-resistant $S$. aureus, MupRSA). Mupirocin resistance can be expressed at low (low level mupirocin-resistant $S$. aureus - LLMupRSA) or high level (high level mupirocin-resistant S. aureus - HL-MupRSA) and may be determined by mechanisms of different genetic background $(11,12)$. LL-MupRSA resistance is associated with mutations in the physiological ileS gene, whereas HL-MupRSA with the acquisition of a new mupA or mupB gene (ileS2) encoding a modified isoleucine-tRNA synthetase opisano u $S$. aureus gen mecB występujący w dużym plazmidzie pSAWWU4229_1, o wielkości 84,599 bp łącznie z genami oporności na aminoglikozydy, makrolidy i tetracykliny. Gen $m e c \mathrm{~B}$ warunkował podobny fenotyp oporności na antybiotyki beta-laktamowe jak geny mecA i mecC (7). Również w 2018 roku u Macrococcus caseolyticus opisano gen mecD, który ulegał ekspresji w szczepie $S$. aureus, a spektrum warunkowanej oporności obejmowało wszystkie antybiotyki beta-laktamowe łącznie z ceftaroliną (8). W przypadku wariantów o fenotypie HA-MRSA meticylino-oporności najczęściej towarzyszy również oporność na antybiotyki z innych grup, przez co stanowią tym większe zagrożenie, szczególnie dla pacjentów z zaburzeniami odporności (5). S. aureus jest istotnym składnikiem flory fizjologicznej człowieka, a nosicielstwo, które dotyczy najczęściej 10-30\% ogólnej populacji, może stanowić istotny czynnik predysponujący do zakażeń o charakterze endogennym. Ryzyko infekcji u osób bezobjawowo skolonizowanych jest co najmniej trzykrotnie wyższe w porównaniu do osób niebędących nosicielami, a w przypadku szczepów MRSA ryzyko objawowego zakażenia jest nawet czterokrotnie wyższe w porównaniu do MSSA (9). Bezobjawowa kolonizacja jest to również ważny czynnik ryzyka transmisji drobnoustroju z nosiciela na innych ludzi lub do środowiska, co stanowi potencjalne zagrożenie szczególnie dla pacjentów hospitalizowanych. Ponadto, w przypadku izolatów MRSA mecB- pozytywnych, o ile ten typ oporności się rozprzestrzeni u $S$. aureus, istnieje również ryzyko horyzontalnego transferu genów mec do innych szczepów $S$. aureus i/lub innych gatunków w obrębie rodzaju Staphylococcus $(5,7)$.

Osoby, mające $\mathrm{z}$ racji wykonywanego zawodu bezpośredni kontakt z chorymi: lekarze, pielęgniarki, położne, ratownicy medyczni, ale również studenci medycyny, nie powinny stanowić zagrożenia zakażeniem tymi niebezpiecznymi patogenami.

Lekiem powszechnie stosowanym do miejscowej eradykacji $S$. aureus w jamie nosowej, jest mupirocyna (skuteczność 4-7 dniowej terapii na poziomie 90\%). Mupirocyna działa na komórki bakteryjne poprzez blokowanie syntetazy izoleucyno-tRNA, IleS, prowadząc do zahamowania procesu biosyntezy białek (10). Mupirocyna wywołuje efekt bakteriobójczy w stosunku do drobnoustrojów Gram-dodatnich, w tym gronkowca złocistego, zarówno MSSA jak i MRSA. Jednak w ostatnich latach coraz częściej odnotowuje się przypadki niepowodzeń dekolonizacji S. aureus przy użyciu mupirocyny, co związane jest $\mathrm{z}$ pojawianiem się wariantów niewrażliwych na ten lek (mupirocin-resistant S. aureus, MupRSA). Oporność na mupirocynę może się wyrażać na niskim (LL-MupRSA - low level mupirocin-resistant S. aureus) lub wysokim poziomie (HL-MupRSA - high level mupirocin-resistant $S$. aureus) i może być determinowana mechanizmami o różnym podłożu genetycznym (11, 
protein, IleS2 $(10,12)$. According to literature data, the percentage of resistant isolates in the population varies within a wide range from $<1 \%$ to even $85 \%$ (10).

The aim of the study was to assess and compare the level of asymptomatic $S$. aureus colonization, taking into account both sensitive, MSSA, and methicillin-resistant, MRSA, variants in two populations of young, generally healthy people, i.e. medical students of the Medical University of Warsaw. Susceptibility of selected S. aureus isolates to mupirocin was also determined in order to verify the possibility of using empiric mupirocin antibiotic therapy for carrier state eradication. The molecular mechanism conditioning the $\mathrm{R}$ phenotype (resistance) was determined for all MRSA and/or MupRSA strains.

\section{MATERIALS AND METHODS}

\section{Bacterial strains}

The study material consisted of a total of 955 clinical samples collected from the right and left nasal vestibule mucosa from the third year medical students of the Warsaw Medical University. The swabs were from the years 2014-2015 (489 samples) and 20152016 (466 samples).

The swabs were plated using the streaking technique on $5 \%$ sheep blood agar and Chapman agar media. Incubation was carried out under aerobic conditions at $37^{\circ} \mathrm{C}$ for $24-48$ hours to grow and isolate potential $S$. aureus strains.

\section{Identification of bacterial strains}

All selected colonies were isolated and the strains were identified using a commercial Pastorex Staph Plus Kit (Bio-Rad), according to the manufacturer's instructions and/or an automated VITEK MS (Biomerieux) system, using the MALDI-TOF technique (Matrix Assisted Laser Desorption Ionization Time-of -Flight).

\section{Determination of strains susceptibility to antibiotics}

Susceptibility to methicillin and mupirocin was determined using a disk diffusion method in a phenotypic test using cefoxitin FOX $30 \mu \mathrm{g}$ (Oxoid) and mupirocin MUP $200 \mu \mathrm{g}$ discs, in accordance with the EUCAST recommendations (European Committee on Antimicrobial Susceptibility Testing) (13). Interpretation criteria of the obtained reading values are given in Table I. The MIC value to mupirocin was also determined using a broth microdilution method in accordance with the EUCAST.

$S$. aureus strains were classified into the following categories on the basis of the obtained results: MSSA methicillin-susceptible S. aureus; MRSA - methicillinresistant $S$. aureus; MupSSA - mupirocin-susceptible S. aureus; LL-MupRSA-low level mupirocin-resistant S. aureus; HL-MupRSA - high level mupirocinresistant $S$. aureus.
12). Oporność typu LL-MupRSA związana jest z mutacjami $\mathrm{w}$ obrębie fizjologicznego genu ileS, natomiast HL-MupRSA z nabyciem nowego genu mupA lub тирB (ileS2), kodującego zmodyfikowane białko syntetazy izoleucyno-tRNA, IleS2 $(10,12)$. Według danych literaturowych odsetek izolatów opornych w populacji waha się w szerokim zakresie od $<1 \%$ do nawet $85 \%$ (10).

Celem podjętych badań była ocena oraz porównanie poziomu bezobjawowej kolonizacji S. aureus, z uwzględnieniem wariantów zarówno wrażliwych, MSSA, jak i opornych na meticylinę, MRSA, w dwóch populacjach młodych, ogólnie zdrowych osób, którą stanowili studenci medycyny Warszawskiego Uniwersytetu Medycznego. W celu weryfikacji możliwości stosowania empirycznej antybiotykoterapii mupirocyną do eradykacji nosicielstwa, określono również wrażliwość wyselekcjonowanych izolatów $S$. aureus na mupirocynę. Dla wszystkich szczepów opornych MRSA i/lub MupRSA określono mechanizm molekularny determinujący fenotyp R (resistant).

\section{MATERIAŁY I METODY}

\section{Szczepy bakteryjne}

Materiał badania stanowiło łącznie 955 próbek klinicznych, pobranych z błony śluzowej prawego i lewego przedsionka jamy nosowej od studentów trzeciego roku kierunku lekarskiego, Warszawskiego Uniwersytetu Medycznego. Wymazy pochodziły z lat 2014-2015 (489 próbek) oraz 2015-2016 (466 próbek).

Wymazy posiewano, przy zastosowaniu techniki posiewu redukcyjnego, na podłoża agar z 5\% krwią baranią oraz na podłoże Chapman agar. Inkubację prowadzono w warunkach tlenowych w temperaturze $37^{\circ} \mathrm{C}$, przez 24-48 godzin, w celu wyhodowania oraz wyizolowania potencjalnych szczepów Staphylococcus aureus.

\section{Identyfikacja szczepów bakteryjnych}

Wszystkie wyselekcjonowane kolonie izolowano, a następnie identyfikowano szczepy przy zastosowaniu komercyjnego zestawu Pastorex Staph Plus (Bio Rad), zgodnie $\mathrm{z}$ instrukcją producenta $\mathrm{i} /$ lub automatycznego systemu VITEK MS (Biomerieux), wykorzystującego technikę MALDI-TOF (Matrix Assisted Laser Desorption Ionization Time-of-Flight).

\section{Oznaczenie wrażliwości szczepów na antybiotyki}

Wrażliwość na meticylinę oraz na mupirocynę określano posługując się metodą dyfuzyjno-krążkową w teście fenotypowym, przy użyciu krążków z cefoksytyną, FOX $30 \mu \mathrm{g}$ oraz z mupirocyną MUP $200 \mu \mathrm{g}$ (Oxoid), zgodnie z rekomendacjami EUCAST (European Committee on Antimicrobial Susceptibility Testing) (13). Kryteria interpretacji uzyskanych wartości odczytów zamieszczono w Tabeli I. Wartość MIC dla mupirocyny oznaczono przy zastosowaniu metody mikro-rozcieńczeń w podłożu płynnym, według EUCAST (13). 
Table I. Criteria for the determination of $S$. aureus strain susceptibility to cefoxitin and mupirocin, in accordance with EUCAST recommendations (13)

Tabela I. Kryteria oznaczenia wrażliwości szczepów S. aureus na cefoksytynę oraz mupirocynę, zgodnie z rekomendacjami EUCAST (13)

\begin{tabular}{|l|c|c|c|}
\hline \multirow{2}{*}{\multicolumn{1}{c|}{ Antibiotic }} & \multicolumn{3}{|c|}{ EUCAST recommendations } \\
\cline { 2 - 4 } & Susceptibility & Intermediate & Resistance \\
\hline Cefoxitin (FOX) & $\geq 22 \mathrm{~mm}$ & - & $<22 \mathrm{~mm}$ \\
\hline Mupirocin (MUP) & $\geq 30 \mathrm{~mm}$ & $29-18 \mathrm{~mm}$ & $<18 \mathrm{~mm}$ \\
\hline
\end{tabular}

Legend: EUCAST - European Committee on Antimicrobial Susceptibility Testing

\section{Genomic DNA isolation}

Bacterial genomic DNA was isolated using a commercial Genomic Mini kit (A\&A Biotechnology).

Bacterial culture on BHI medium in the logarithmic growth phase was transferred to 1,5-ml eppendorf tubes and centrifuged for $3 \mathrm{~min}$ at 13,000 RPM. The supernatant was removed and the pellet was resuspended in $100 \mu \mathrm{l}$ of Tris buffer. Lysostaphin $1 \mathrm{U} / \mu \mathrm{l}(10 \mu \mathrm{l})$ was added and incubated for $30 \mathrm{~min}$ at $37^{\circ} \mathrm{C}$. Then, $200 \mu \mathrm{LT}$ lysis solution and $20 \mu \mathrm{l}$ proteinase $\mathrm{K}$ was added, mixed and incubated successively: $20 \mathrm{~min}$ at $37^{\circ} \mathrm{C}$ and $5 \mathrm{~min}$ at $70^{\circ} \mathrm{C}$. After this steps, the samples were vigorously shaken for $20 \mathrm{~s}$, and subsequently centrifuged for 3 min at 13,000 RPM. The supernatant obtained after centrifugation was loaded on minicolumns for genomic DNA purification and centrifuged $1 \mathrm{~min}$ at 13,000 RPM. After two washes with washing solution A1, the minicolumns were transferred to new sterile $1,5 \mathrm{ml}$ eppendorf tubes. Tris buffer $(100 \mu \mathrm{l})$, heated to $75^{\circ} \mathrm{C}$, was applied to the column beds and incubated for $5 \mathrm{~min}$ at room temperature, followed by centrifugation for 1 min at 13,000 RPM. After centrifugation, minicolumns were removed and genomic DNA was stored at $-20^{\circ} \mathrm{C}$ until further analysis.

\section{Detection of resistance genes}

The presence of the mec $\mathrm{A}$ and $m e c \mathrm{C}$ genes was determined using PCR and the appropriate primer pairs: MecA-R and MecA-F - only for the mecA gene, 99 bp product; MecC FP and MecC RP - for the mecC gene, 138 bp product; MecC multi FP and MecC RP for both mecA and mec $\mathrm{C}$ genes, $356 \mathrm{bp}$ product; $\mathrm{MecC}$ multi FP and MecC multi RP - only for the mec $\mathrm{C}$ gene, $718 \mathrm{bp}$ product, according to the procedure described by Francois et al. (14) and Stegger et al. (15). The presence of the mupA gene was verified using PCR and the following primers: HWmupA-F and HWmupA-R, which amplified a 447 bp product, according to Seah et al. (16).

\section{RESULTS}

The study group consisted of 955 students, participants of the third year of medical studies of the Warsaw Medical University. The average age of the
Na podstawie uzyskanych wyników szczepy $S$. aureus zaklasyfikowano do następujących kategorii: MSSA - methicillin-susceptible S. aureus; MRSA methicillin-resistant $S$. aureus; MupSSA - mupirocin-susceptible $S$. aureus; LL-MupRSA - low level mupirocin-resistant $S$. aureus; HL-MupRSA - high level mupirocin-resistant $S$. aureus.

\section{Izolacja genomowego DNA}

Genomowe DNA bakterii izolowano $\mathrm{z}$ bakterii przy użyciu komercyjnego zestawu Genomic Mini, A\&A Biotechnology.

Do probówek typu eppendorf przenoszono po $1,5 \mathrm{ml}$ płynnej hodowli bakteryjnej na podłożu BHI w fazie wzrostu logarytmicznego i wirowano 3 min przy 13 tys. RPM. Supernatant usuwano, zaś osad zawieszano w $100 \mu \mathrm{l}$ buforu Tris. Dodawano po $10 \mu 1$ lizostafiny, o stężeniu $1 \mathrm{U} / \mu \mathrm{l}$ i inkubowano przez $30 \mathrm{~min}$ w temperaturze $37^{\circ} \mathrm{C}$. Następnie dodawano po $200 \mu 1$ roztworu lizującego LT i po $20 \mu \mathrm{l}$ proteinazy $\mathrm{K}$, mieszano i poddawano kolejno inkubacji: 20 min w temperaturze $37^{\circ} \mathrm{C}$ oraz $5 \mathrm{~min} \mathrm{w} 70^{\circ} \mathrm{C}$. Po tym etapie próbki intensywnie wytrząsano przez $20 \mathrm{~s}$, po czym wirowano 3 min przy 13 tys. RPM. Uzyskany supernatant nanoszono na minikolumny przeznaczone do oczyszczania genomowego DNA i wirowano 1 min przy 13 tys. RPM. Po dwukrotnym płukaniu roztworem płuczącym A1, minikolumny przenoszono do nowych jałowych probówek typu eppendorf na 1,5 ml. Na złoże w kolumnach nanoszono po $100 \mu 1$ ogrzanego do temp $75^{\circ} \mathrm{C}$ buforu Tris i inkubowano przez 5 min w temperaturze pokojowej, po czym wirowano przez 1 min przy 13 tys. RPM. Po zwirowaniu minikolumny usuwano, a uzyskane genomowe DNA przechowywano $\mathrm{w}$ temperaturze $-20^{\circ} \mathrm{C}$ do momentu wykorzystania do dalszych analiz.

\section{Wykrywanie genów oporności}

Obecność genów mecA i mecC określano przy zastosowaniu techniki PCR oraz odpowiednich par starterów: MecA-R i MecA-F - tylko dla genu mecA, produkt 99 bp; MecC FP i MecC RP - dla genu mecC, produkt 138 bp; MecC multi FP i MecC RP - dla obydwu genów mec A oraz mec $\mathrm{C}$, produkt $356 \mathrm{bp}$; MecC multi FP i MecC multi RP - tylko dla genu mecC, produkt 718 bp, według procedury opisanej przez Francois $P$ i wsp. 
subjects was 22 years, women accounted for $60,6 \%$ (578 persons) and men for $39,4 \%$ (377 persons). Demographic data of the subjects, including the division into academic years, are presented in Table II.
(14) oraz Stegger M i wsp. (15). Występowanie genu mupA weryfikowano przy zastosowaniu techniki PCR oraz starterów: HWmupA-F i HWmupA-R, uzyskując produkt o wielkości 447 bp, według Seah C i wsp. (16).

Table II. Demographic characteristics of the studied group of students and the occurrence of S. aureus carrier state

Tabela II. Charakterystyka demograficzna studentów z grupy badanej oraz występowanie nosicielstwa $S$. aureus

\begin{tabular}{|c|c|c|c|c|c|c|c|c|}
\hline \multirow{3}{*}{$\begin{array}{l}\text { Year of strain } \\
\text { isolation }\end{array}$} & \multicolumn{3}{|c|}{$\begin{array}{l}\text { Demographic data } \\
\text { of the studied group }\end{array}$} & \multirow{3}{*}{$\begin{array}{c}\text { S. aureus } \\
\text { carriers (\%) }\end{array}$} & \multicolumn{4}{|c|}{ Number of $S$. aureus carriers } \\
\hline & \multirow[b]{2}{*}{ Age } & \multirow[b]{2}{*}{ Male } & \multirow{2}{*}{$\begin{array}{l}\text { Number of } \\
\text { students } \\
\text { in studied } \\
\text { group }\end{array}$} & & \multicolumn{2}{|c|}{ MRSA } & \multicolumn{2}{|c|}{ MupRSA } \\
\hline & & & & & $\begin{array}{c}\text { Studied } \\
\text { group (\%) }\end{array}$ & $\begin{array}{c}\text { S. aureus } \\
\text { carriers } \\
\text { group }(\%)\end{array}$ & $\begin{array}{c}\text { Studied } \\
\text { group }(\%)\end{array}$ & $\begin{array}{c}\text { S. aureus } \\
\text { carriers } \\
\text { group (\%) }\end{array}$ \\
\hline $\begin{array}{c}2014-2016 \\
\text { (whole period) }\end{array}$ & 22 & $\begin{array}{l}\text { F } 578 \\
\text { M } 377\end{array}$ & 955 & $245(25,7)$ & $1 / 955(0,1)$ & $1 / 245(0,4)$ & $2 / 955(0,2)$ & $2 / 245(0,82)$ \\
\hline $2014-2015$ & 22 & $\begin{array}{l}\text { F } 278 \\
\text { M } 211\end{array}$ & 489 & $106(21,7)$ & $0 / 489(0)$ & 0/106 (0) & 0/489 (0) & 0/106 (0) \\
\hline $2015-2016$ & 22 & $\begin{array}{l}\text { F } 300 \\
\text { M } 166\end{array}$ & 466 & $139(29,9)$ & $1 / 466(0,21)$ & $1 / 139(0,72)$ & $2 / 466(0,42)$ & $2 / 139(1,4)$ \\
\hline
\end{tabular}

Legend: F - female; M - male; MRSA - methicillin resistant S. aureus; MupRSA - mupirocin resistant S. aureus

Table III. Characterization of phenotype and genotype of methicillin and mupirocin-resistance of selected MSSA/MupRSA and MRSA/MupRSA variants

Tabela III. Charakterystyka fenotypu oraz genotypu oporności na meticylinę i mupirocynę wyselekcjonowanych wariantów MSSA/MupRSA oraz MRSA/MupRSA

\begin{tabular}{|c|c|c|c|c|c|c|c|c|}
\hline \multirow{3}{*}{$\begin{array}{l}\text { S. aureus } \\
\text { strain }\end{array}$} & \multicolumn{5}{|c|}{ Phenotype of resistance } & \multicolumn{3}{|c|}{ Genotype of resistance } \\
\hline & \multicolumn{2}{|r|}{ MRSA } & \multicolumn{3}{|c|}{ MupRSA } & \multicolumn{2}{|c|}{ MRSA } & \multirow{2}{*}{$\begin{array}{c}\text { MupRSA } \\
\text { mupA }\end{array}$} \\
\hline & $\begin{array}{l}\text { FOX } 30 \\
(\varnothing \mathrm{mm})\end{array}$ & $\begin{array}{c}\text { Interpretation* } \\
\mathbf{R} / \mathbf{I} / \mathbf{S}\end{array}$ & $\begin{array}{c}\text { MUP 200 } \\
(\varnothing \mathrm{mm})\end{array}$ & $\begin{array}{l}\mathrm{MIC}_{\text {MUP }} \\
(\mathrm{mg} / \mathrm{L})\end{array}$ & $\begin{array}{c}\text { Interpretation* } \\
\mathbf{R} / \mathbf{I} / \mathbf{S}\end{array}$ & mecA & $\operatorname{mec} \mathbf{C}$ & \\
\hline SA95 & 34 & S & 6 & 1024 & HL-R & - & - & + \\
\hline SA208 & 14 & $\mathrm{R}$ & 6 & 1024 & HL-R & + & - & + \\
\hline
\end{tabular}

Legend: FOX (ø mm) - cefoxitin (inhibition zone diameter in $\mathrm{mm}$ ); MUP (ø $\mathrm{mm}$ ) - mupirocyna (inhibition zone diameter in $\mathrm{mm}$ ); R/I/S - categories of susceptibility testing: resistance/susceptible, increased exposure (intermediate)/susceptible; HL-R - high level of resistance; MRSA - methicillin-resistant S. aureus; MupRSA - mupirocin-resistant S. aureus; MIC minimal inhibitory concentration; * - interpretation in accordance with EUCAST (European Committee on Antimicrobial Susceptibility Testing) recommendations, 2018

Asymptomatic colonization with $S$. aureus strains in the nasal vestibules was found in a total of 245 people, which was $25,7 \%$ of the study group, and the level of colonization in successive years was $21,7 \%$ and $29,9 \%$, respectively. $113 / 245(46 \%)$ of the colonized subjects were women, while 132/245 (54\%) were men. The percentage of colonized subjects in relation to total population of women and men was $19,5 \%$ and $35 \%$, respectively. 243 isolates showed the MSSA/ MupSSA phenotype, one strain showed high-level resistance only to mupirocin MSSA/MupRSA (mecA/ mecC-negative, mupA-positive genotype) and one isolate showed simultaneous resistance to methicillin and mupirocin, MRSA/MupRSA (mecA-positive and mupA-positive genotype). Both MSSA/MupRSA and

\section{WYNIKI}

Grupę badaną stanowiło 955 studentów, uczestników trzeciego roku studiów na kierunku lekarskim, Warszawskiego Uniwersytetu Medycznego. Średnia wieku osób badanych wynosiła 22 lata, kobiety stanowiły 60,6\% (578 osób), a mężczyźni 39,4\% (377 osób). Dane demograficzne osób badanych z uwzględnieniem podziału na lata akademickie przedstawiono w Tabeli II. Bezobjawową kolonizację szczepami S. aureus w przedsionkach jamy nosowej stwierdzono u łącznie 245 osób, co stanowi 25,7\% grupy badanej, a poziom kolonizacji w poszczególnych latach wynosił odpowiednio $21,7 \%$ oraz $29,9 \%$. 113/245 (46\%) 
MRSA/MupRSA isolates were from the 2015-2016 academic year, and their incidence was $0,1 \%$ and $0,2 \%$, respectively. Detailed data on the number and percentage of isolated $S$. aureus strains in the student population, as well as on the number and proportion of MRSA and/or MupRSA resistant variants, including the division into years, are presented in Table II. The characteristics of the phenotype and resistance genotype of the selected MSSA/MupRSA and MRSA/ MupRSA variants are presented in Table III.

\section{DISCUSSION}

S. aureus carrier state can be permanent (applies to 6-37\%, on average $20 \%$ of the population) or transient (9-70\%, an average of $30 \%$ ), and asymptomatic $S$. aureus colonization never occurs in about $50 \%$ (in the range from 2 to $73 \%$ ) of healthy adults $(17,18)$. $S$. aureus most often inhabits the mucous membrane of the nasal cavity (10-48\% of carriers) and throat (4-64\%), gastrointestinal tract (17-31\%) and skin on which it particularly prefers warm and moist places, i.e. the skin of the armpit (about 8\%), groin (up to $63 \%$ ), chest area, abdomen (15\%) and crotch (about $22 \%)(19)$. These data may vary significantly and this is related not only to the location of the sample site, but also to the characteristics of the study group and is dependent on such factors as age, sex, race, origin, lifestyle and immune status of the host organism. The success of colonization depends to a large extent on the properties of the microorganism itself, its genotype, global regulatory systems, and the environmental conditions, in which this genotype is expressed (19, 20).

The experimental group analyzed in this study consisted of young adults, generally healthy people, participants of the third year medical studies of one of the major Polish medical universities. In the sampling period (swabs from the nasal cavity), the students were before the clinical course stage, so the average colonization level of $25,7 \%$ in this group is consistent with literature data for the general population (19) and seems to be reasonable (no special risk factors). Considering the specifics of the examined group, these results are similar to those obtained by researchers in other countries, almost identical to those reported in China (23,2\%) (21), higher than data for Tanzania (21\%) (22) and significantly lower than results obtained in Japan and the Czech Republic (35,7\% and $32 \%$, respectively) $(23,24)$. In Poland in 2011, a similar study was conducted on medical students from Gdańsk, obtaining a lower result $(19,2 \%)$ than the one in the present study (25).

Considering the level of $S$. aureus colonization in the two analyzed periods, an upward trend can be osób skolonizowanych stanowiły kobiety, natomiast 132/245 (54\%) stanowili mężczyźni. Odsetek osób skolonizowanych względem całej populacji kobiet i mężczyzn wynosił odpowiednio $19,5 \%$ oraz $35 \%$. 243 izolaty wykazywały fenotyp MSSA/MupSSA, jeden szczep wykazywał oporność wysokiego stopnia jedynie na mupirocynę MSSA/MupRSA (genotyp $m e c \mathrm{~A} / m e c \mathrm{C}$ - negatywny, mupA- pozytywny) i jeden izolat wykazywał jednoczesną oporność na meticylinę oraz mupirocynę. MRSA/MupRSA (genotyp mecApozytywny oraz mupA- pozytywny). Obydwa szczepy MSSA/MupRSA oraz MRSA/MupRSA zostały wyizolowane $\mathrm{z}$ próbek pozyskanych $\mathrm{w}$ roku akademickim 2015-2016, a częstość ich występowania wynosiła odpowiednio $0,1 \%$ oraz $0,2 \%$. Szczegółowe dane dotyczące liczby oraz udziału wyizolowanych szczepów $S$. aureus w populacji studentów badanych, jak również dotyczące liczby oraz udziału wariantów opornych MRSA i/lub MupRSA, z uwzględnieniem podziału na lata, przedstawiono w Tabeli II. Charakterystykę fenotypu oraz genotypu oporności wyselekcjonowanych wariantów MSSA/MupRSA oraz MRSA/MupRSA, przedstawiono w Tabeli III.

\section{DYSKUSJA}

Nosicielstwo S. aureus może mieć charakter stały (dotyczy $6-37 \%$, średnio $20 \%$ populacji) lub przejściowy (9-70\%, średnio 30\%), a u około 50\% (w zakresie od 2 do $73 \%$ ) zdrowych, dorosłych osób bezobjawowa kolonizacja $S$. aureus nigdy nie występuje $(17,18)$. Gronkowiec złocisty u nosicieli najczęściej zasiedla błonę śluzową jamy nosowej (10 - 48\% nosicieli) oraz gardła $(4-64 \%)$, przewód pokarmowy (17-31\%) oraz skórę, na której szczególnie preferuje miejsca ciepłe i wilgotne, czyli skórę pach (około $8 \%$ ), pachwin (nawet do 63\%), okolic klatki piersiowej, brzucha (15\%) oraz krocza (około 22\%) (19). Dane te mogą się znacząco różnić i jest to związane nie tylko z lokalizacją miejsca pobieranej próby, ale również z charakterystyką grupy badanej i jest zależne od takich czynników jak m.in.: wiek, płeć, rasa, pochodzenie, prowadzony tryb życia oraz status immunologiczny organizmu gospodarza. Sukces kolonizacji w dużej mierze zależy również od właściwości samego drobnoustroju, jego genotypu, globalnych systemów regulacyjnych oraz od warunków środowiskowych, w których ten genotyp się wyraża $(19,20)$.

Analizowaną w niniejszej pracy grupę badaną stanowili młodzi dorośli, ogólnie zdrowi ludzie, uczestnicy trzeciego roku studiów na kierunku lekarskim jednej z dużych polskich uczelni medycznych. W okresie, kiedy pobierano próbki (wymazy z jamy nosowej), studenci byli przed etapem zajęć klinicznych, więc uzyskany średni poziom kolonizacji w tej grupie na 
observed from $21,7 \%$ in the $2014-2015$ academic year, to $29,9 \%$ in $2015-2016$, which, however, should not be alarming, because both values are within statistical data limits. However, it is worth noting that no MRSA or MupRSA colonization was found among students in the 2014-2015 academic year, while both these variants accounted for $0,21 \%(1 / 466)$ and $0,42 \%(2 / 466)$ in the population from the $2015-2016$ academic year, respectively, which was $0,1 \%$ and $0,2 \%$ of the entire analyzed population of 955 subjects. One of the isolates exhibited simultaneously methicillinresistant phenotype, dependent on the mecA gene, and a high mupirocin resistance $\left(\mathrm{MIC}_{\mathrm{MUP}}=1024 \mathrm{mg} / \mathrm{L}\right)$, conditioned by mupA. The emergence of multidrugresistant alarm pathogens, non-susceptible to the most commonly used eradication antibiotic therapies, in the population of medical students is worrying both due to the risk of transmission of resistant microorganisms from the host to other people or to the environment as well as vertical and/or horizontal transfer of resistance genes between bacterial strains. According to literature data, MRSA colonization may even proceed faster and easier compared to MSSA variants (selection of resistant variants during other, standard antibiotic therapies), and the risk of symptomatic infection for these variants is higher than for MSSA colonization (17). In this context, it seems that a medical student, and in the future a doctor, who carries multidrug-resistant $S$. aureus strains can pose a serious threat mainly for patients, but also for themselves and other people in their immediate environment. This imposes the need to eradicate the carrier state $(26,27)$, however, the emergence of mupirocin-resistant $S$. aureus isolates, especially MRSA variants colonizing healthcarerelated people contacting patients, is worrying, because it can significantly hinders the effective elimination of potential epidemic outbreaks.

Mupirocin resistance in both isolates detected in the work was expressed at a high level and was associated with the presence of the mupA gene, carried on mobile genetic elements, which further raises the importance of the problem in the epidemiological aspect (10).

However, comparing the present results with literature (Tanzania - MRSA carrier state among medical students $-0,3 \%$, Serbia - 0,37\%, Poland, Gdańsk - 0,93\%) $(22,25,28)$, it can be concluded that the level of MRSA and MupRSA colonization (10) among medical students in Warsaw $(0,1 \%$ and $0,2 \%$, respectively) is low.

\section{CONCLUSIONS}

The level of $S$. aureus colonization among the studied students was within the limits of statistics for a generally healthy population, but showed an upward poziomie $25,7 \%$, jest wynikiem zgodnym z danymi literaturowymi dla populacji ogólnej (19) i wydaje się być zasadny (brak czynników szczególnego ryzyka). Uwzględniając specyfikę grupy badanej, uzyskane wyniki są zbliżone do uzyskanych przez badaczy w innych krajach, prawie identyczne do opisywanych w Chinach $(23,2 \%)$ (21), wyższe od danych dla Tanzanii (21\%) (22) i jednocześnie znacząco niższe od danych uzyskanych w Japonii oraz Czechach (35,7\%; $32 \%)(23,24)$. W Polsce w 2011 przeprowadzono podobne badanie na studentach medycyny z Gdańska, uzyskując wynik niższy $(19,2 \%)$ od otrzymanego w niniejszym badaniu (25).

Uwzględniając poziom kolonizacji $S$. aureus w dwóch badanych okresach, można zaobserwować tendencję wzrostową z $21,7 \% \mathrm{w}$ roku akademickim 2014-2015, do 29,9\% w 2015-2016, co jednak nie powinno być niepokojące, ponieważ zarówno jedna, jak i druga wartość mieści się $w$ granicach danych statystycznych. Warto jednak zaznaczyć, iż wśród studentów w roku akademickim 2014-2015 nie stwierdzono kolonizacji MRSA ani MupRSA, natomiast w populacji $\mathrm{z}$ roku akademickiego 2015-2016 warianty te stanowity odpowiednio $0,21 \%(1 / 466)$ oraz $0,42 \%$ (2/466), co stanowi $0,1 \%$ i $0,2 \%$ względem całej analizowanej populacji liczącej 955 osób. Jeden z izolatów wykazywał jednocześnie fenotyp oporności na meticylinę, zależny od genu mecA oraz wysokiej oporności na mupirocynę $\left(\mathrm{MIC}_{\mathrm{MUP}}=1024 \mathrm{mg} / \mathrm{L}\right)$, zależny od mupA. Pojawienie się w populacji studentów medycyny wieloleko-opornych patogenów alarmowych, jednocześnie niewrażliwych na najpowszechniej stosowaną antybiotykoterapię eradykacyjną budzi niepokój, zarówno ze względu na ryzyko transmisji opornych drobnoustrojów z nosiciela na inne osoby lub do środowiska, jak i wertykalnego i/ lub horyzontalnego transferu samych genów oporności między szczepami bakteryjnymi. Według danych literaturowych, kolonizacja MRSA może nawet przebiegać szybciej i łatwiej w porównaniu do wariantów MSSA (selekcja wariantów opornych w trakcie innych, standardowych antybiotykoterapii), a ryzyko objawowego zakażenia w przypadku tych wariantów jest wyższe niż w przypadku kolonizacji MSSA (17). W tym kontekście wydaje się, że student medycyny, a w przyszłości lekarz, będący nosicielem wieloleko-opornych szczepów $S$. aureus może stanowić poważne zagrożenie głównie dla pacjentów, ale również dla siebie samego oraz innych osób z najbliższego otoczenia. Narzuca to konieczność eradykacji nosicielstwa $(26,27)$, jednakże pojawianie się izolatów $S$. aureus opornych na mupirocynę, zwłaszcza w przypadku wariantów MRSA kolonizujących osoby związane ze służbą zdrowia i kontaktujące się z pacjentami, jest niepokojące, ponieważ może znacząco utrudniać skuteczną eliminację potencjalnych ognisk epidemicznych. 
trend. The carrier state of multidrug-resistant strains among future doctors was very rare, but every such case is worrying and is a real threat to patients. The emergence of carrier state of $S$. aureus strains resistant to high mupirocin concentrations suggests that topical eradication antibiotic therapy should be used with caution.

\section{REFERENCES}

1. Rozporządzenie Ministra Zdrowia, z dnia 23 grudnia 2011 r., w sprawie listy czynników alarmowych, rejestrów zakażeń szpitalnych i czynników alarmowych oraz raportów o bieżącej sytuacji epidemiologicznej szpitala. Listę czynników alarmowych określa załącznik nr 1 do rozporządzenia: http://www2.mz.gov.pl/wwwfiles/ma_struktura/docs/zal1_epidemszpital_27122011. pdf

2. World Health Organization. WHO Publishes List of Bacteria for Which New Antibiotics are Urgently Needed; 2017. Available from: http://www.who. $\mathrm{int} / \mathrm{medicines} /$ publications/WHO-PPL-Short Summary_25Feb-ET_NM_WHO.pdf

3. Shrivastava SR, Shrivastava PS, Ramasamy J. World health organization releases global priority list of antibiotic-resistant bacteria to guide research, discovery, and development of new antibiotics. J Med Soc 2018 [cited 2018 Oct 21];32:76-7. Available from: http://www. jmedsoc.org/temp/JMedSoc32176-6635584_015035.pdf

4. Tong SY, Davis JS, Eichenberger E, et al. Staphylococcus aureus Infections: Epidemiology, Pathophysiology, Clinical Manifestations, and Management. Clin Microbiol Rev 2015;28(3):603-61.

5. Lakhundi S, Zhang K. Methicillin-Resistant Staphylococcus aureus: Molecular Characterization, Evolution, and Epidemiology. ClinMicrobiol Rev 2018;31(4):pii: e00020-18.

6. Młynarczyk A, Młynarczyk B, Kmera-Muszyńska M, et al. Mechanisms of the resistance and tolerance to beta-lactam and glycopeptide antibiotics in pathogenic Gram-positive cocci. Mini-Review Medicinal Chemistry 2009;9(13):1527-37.

7. Becker K, van Alen S, Idelevich EA, et al. PlasmidEncoded Transferable mecB-Mediated Methicillin Resistance in Staphylococcus aureus. Emerg Infect Dis 2018;24(2):242-8.

8. Schwendener S, Cotting K, Perreten V. Novel methicillin resistance gene mec $\mathrm{D}$ in clinical Macrococcus caseolyticus strains from bovine and canine sources. Sci Rep 2017;7:43797.

9. Safdar N, Bradley EA. The risk of infection after nasal colonization with Staphylococcus aureus. Am J Med 2008;121:310-5.

10. Poovelikunnel T, Gethin G, Humphreys H. Mupirocin resistance: clinical implications and potential alternatives for the eradication of MRSA. J Antimicrob Chemother 2015;70(10):2681-92.
W przypadku obydwu wyselekcjonowanych w pracy izolatów oporność na mupirocynę wyrażała się na wysokim poziomie i związana była $z$ obecnością genu mupA, przenoszonego na ruchomych elementach genetycznych, co dodatkowo podnosi rangę problemu w aspekcie epidemiologicznym (10).

Jednakże porównując uzyskane wyniki z literaturą (Tanzania - nosicielstwo MRSA wśród studentów medycyny - 0,3\%; Serbia - 0,37\%; Polska, Gdańsk $0,93 \%)(22,25,28)$, można stwierdzić, iż poziom kolonizacji MRSA oraz MupRSA (10), wśród studentów medycyny w Warszawie $(0,1 \%$ i $0,2 \%)$ jest niski.

\section{PODSUMOWANIE}

Poziom kolonizacji S. aureus wśród badanych studentów mieścił się w granicach statystyk dla populacji ogólnie zdrowej, ale wykazywał tendencję wzrostową. Nosicielstwo wieloleko-opornych szczepów wśród przyszłych lekarzy występowało bardzo rzadko, ale każdy taki przypadek budzi niepokój i jest realnym zagrożeniem dla pacjentów. Pojawienie się nosicielstwa szczepów $S$. aureus opornych na wysokie stężenia mupirocyny sugeruje, że miejscową terapię eradykacyjną z zastosowaniem antybiotyków należy stosować $z$ rozwagą.

11. Mlynarczyk B, Mlynarczyk A, Kmera-Muszynska M, et al. Mechanisms of resistance to antimicrobial drugs in pathogenic Gram-positive cocci. Mini RevMed Chem 2010;10(10):928-37.

12. Hetem DJ, Bonten MJ. Clinical relevance of mupirocin resistance in Staphylococcus aureus. J Hosp Infect 2013;85(4):249-56.

13. The European Committee on Antimicrobial Susceptibility Testing. Breakpoint tables for interpretation of MICs and zone diameters. Version 8.1, 2018. http://www.eucast.org/ fileadmin/src/media/PDFs/EUCAST_files/Breakpoint_ tables/v_8.1_Breakpoint_Tables.pdf

14. Francois P, Huyghe A, Charbonnier Y, et al. Use of an automated multiple-locus, variable-number tandem repeat-based method for rapid and high-throughput genotyping of Staphylococcus aureus isolates. J Clin Microbiol 2005;43(7):3346-55.

15. Stegger M, Andersen PS, Kearns A, et al. Rapid detection, differentiation and typing of methicillinresistant Staphylococcus aureus harbouring either mecA or the new mecA homologue mecA(LGA251). Clin Microbiol Infect 2012;18(4):395-400.

16. Seah C, Alexander DC, Louie L, et al. MupB, a New High-Level Mupirocin Resistance Mechanism in Staphylococcus aureus. Antimicrob Agents Chemother 2012;56(4):1916-20.

17. Lepelletier D, Lucet JC. Controlling methicillin-susceptible Staphylococcus aureus: not simply methicillin-resistant S. aureus revisited. J Hosp Infect 2013;84(1):13-21. 
18. Mehraj J, Witte W, Akmatov MK, et al. Epidemiology of Staphylococcus aureus Nasal Carriage Patterns in the Community. Curr Top Microbiol Immunol 2016;398:55-87.

19. Sollid JU, Furberg AS, Hanssen AM, et al. Staphylococcus aureus: determinants of human carriage. Infect Genet Evol 2014;21:531-41.

20. Szymanek K, Młynarczyk A, Młynarczyk G. Systemy regulacyjne ekspresji genów u Staphylococcus aureus. Postępy Mikrobiol 2009;48(1):7-22. Polish.

21. Ma XX, Sun DD, Wang S, et al. Nasal carriage of methicillin-resistant Staphylococcus aureus among preclinical medical students: epidemiologic and molecular characteristics of methicillin-resistant $S$. aureus clones. Diagn Microbiol Infect Dis 2011;70(1):22-30.

22. Okamo B, Moremi N, Seni J, et al. Prevalence and antimicrobial susceptibility profiles of Staphylococcus aureus nasal carriage among pre-clinical and clinical medical students in a Tanzanian University. BMC Res Notes 2016;27(9):47.

23. Uemura E, Kakinohana S, Higa N, et al. Comparative characterization of Staphylococcus aureus isolates from throats and noses of healthy volunteers. J Infect Dis 2004;57(1):21-4.

24. Holý O, Vlčková J, Matoušková, et al. [The prevalence of nasal carriage of Staphylococcus aureus and methicillin-resistant $S$. aureus (MRSA) among general medicine students of the Palacky University Olomouc]. Epidemiol Mikrobiol Imunol 2015;64(2):98-101. Czech.
25. Piechowicz L, Garbacz K, Wiśniewska K, et al. Screening of Staphylococcus aureus nasal strains isolated from medical students for toxin genes. Folia Microbiol 2011;56(3):225-9.

26. George S, Leasure AR, Horstmanshof D. Effectiveness of Decolonization With Chlorhexidine and Mupirocin in Reducing Surgical Site Infections: A Systematic Review. Dimens Crit Care Nurs 2016;35(4):204-22.

27. Humphreys H, Becker K, Dohmen PM, et al. Staphylococcus aureus and surgical site infections: benefits of screening and decolonization before surgery. J Hosp Infect 2016;94(3):295-304.

28. Cirković I, Djukić S, Vuković D, et al. [Nasal carriage of methicillin-resistant Staphylococcus aureus among medical students of Belgrade University]. Srp Arh Celok Lek 2013;141(5-6):349-53. Serbian.

Received: 16.11.2018

Accepted for publication: 22.01.2019

Otrzymano: 16.11.2018 r.

Zaakceptowano do publikacji:22.01.2019 r.

\section{Address for correspondence: Adres do korespondencji:}

Ksenia Szymanek-Majchrzak, Katedra i Zakład Mikrobiologii Lekarskiej, Warszawski Uniwersytet Medyczny,

ul. T. Chałubińskiego 5, 02-004 Warszawa, tel.: +48 2262827 39, fax: +48 2262827 39, e-mail: ksenia.szymanek-majchrzak@wum.edu.pl 